\title{
A study of conformational behaviour in some hexahydro-2H-isoxazolo[2,3-a]pyridines
}

\author{
Shaikh A. Ali*, Alaaeddin AlSbaiee, and Mohamed I. M. Wazeer \\ Chemistry Department, King Fahd University of Petroleum and Minerals, \\ Dhahran 31261, Saudi Arabia \\ E-mail: shaikh@,kfupm.edu.sa
}

\begin{abstract}
A study of the effects of substituents on the conformational behaviour of a series of hexahydro$2 H$-isoxazolo[2,3-a]pyridines (a 6/5 fused ring system), prepared via nitrone cycloaddition reaction of 4-butyloxycarbonyl-3,4,5,6-tetrahydropyridine-1-oxide with mono- and disubstituted alkenes, has been carried out. Some of these bicyclic cycloaddition products show the presence of two isomers (cis-and trans-fused system), equilibrating via relatively slow nitrogen inversion process, while the rest exist solely as the trans-invertomer. Stereochemistry of the ring fusion was determined by NMR spectral analyses. The effect of substituents and solvents $-\mathrm{CDCl}_{3}$ toluene- $\mathrm{d}_{6}$, and $\mathrm{CD}_{3} \mathrm{OD}$ - on the population ratio of the invertomers and inversion barriers has been investigated. The nitrogen inversion barriers, determined using complete line-shape analysis, are in the range $62.1-72.3 \mathrm{~kJ} \mathrm{~mol}^{-1}$.
\end{abstract}

Keywords: Isoxazoldines, ${ }^{13} \mathrm{C}$ chemical shifts, nitrogen inversion, invertomers, inversion barriers

\section{Introduction}

Among a plethora of functional groups the nitrone functionality has etched a place of distinction in organic synthesis. ${ }^{1}$ The 1,3-dipolar cycloaddition reactions of cyclic nitrones have been extensively used in the synthesis of several interesting natural products containing pyrrolidine and piperidine rings which are widespread in nature. ${ }^{1,2}$ In a recent article, the face selectivity associated with the cycloaddition reactions of a six-membered nitrone containing a substituent furthest from the nitrone moiety i.e. at the $\mathrm{C}(4)$ position (e.g. 1, Scheme 1) has been reported for the first time. ${ }^{3}$ It is often difficult to assign the configuration at various chiral centers of the cycloadducts 3 and $\mathbf{4}$ by spectroscopic analysis owing to complications arising out of slow nitrogen inversion process involving cis- and trans-fused invertomers. The presence of $-\mathrm{N}-\mathrm{O}-$ moiety in an organic molecule (as in the case of isoxazolidines $\mathbf{3}$ and $\mathbf{4}$ ) has a distinctive place in 
conformational analysis ${ }^{4-6}$; oxygen being next to nitrogen raises the barrier to nitrogen inversion to such an extent that the individual invertomers can be identified by NMR spectroscopy. ${ }^{7}$ The previous studies ${ }^{8}$ of nitrogen inversion have greatly contributed to the understanding of several reaction processes. Orientation of the nitrogen lone pair with respect to the bridgehead hydrogen and the trans-/cis-fused invertomer ratio dictate the regiochemical outcome of the peracid oxidation process; the trans and cis invertomers of 5 afford the keto- (6) and synthetically more important aldo-nitrones (7), respectively (Scheme 1). ${ }^{9}$ Therefore, the proper utilization of these second-generation nitrones requires prior information on the stereochemistry of the ring fusion. We have prepared a number of bicyclic isoxazolidines $\mathbf{3}$ and $\mathbf{4}$ of known configurations ${ }^{3}$ using nitrone (1)-alkene (2) cycloaddition reactions to examine the conformational aspects as well as nitrogen inversion process by NMR spectroscopy (Scheme 1). The study would also involve examining the effect of solvents toluene- $\mathrm{d}_{8}, \mathrm{CDCl}_{3}$ and $\mathrm{CD}_{3} \mathrm{OD}$ on the population ratio of the invertomers.

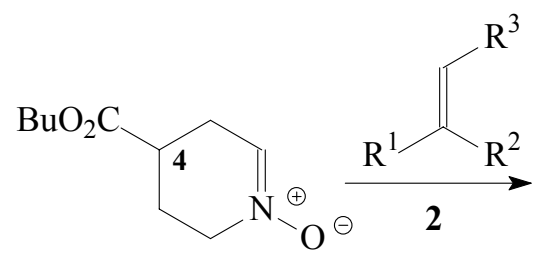

1

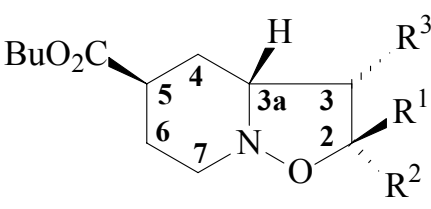

3

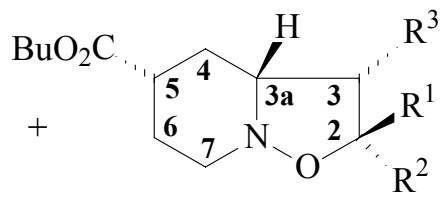

4

a, $\mathrm{R}^{1}=\mathrm{Bu}, \mathrm{R}^{2}=\mathrm{R}^{3}=\mathrm{H}$

b, $\mathrm{R}^{1}=\mathrm{Ph}, \mathrm{R}^{2}=\mathrm{R}^{3}=\mathrm{H}$

c, $\mathrm{R}^{1}=\mathrm{Me}, \mathrm{R}^{2}=\mathrm{CO}_{2} \mathrm{Me}, \mathrm{R}^{3}=\mathrm{H}$

d, $\mathrm{R}^{1}=\mathrm{Me}, \mathrm{R}^{2}=\mathrm{H}, \mathrm{R}^{3}=\mathrm{CO}_{2} \mathrm{Me}$<smiles>[R4][C@H](C)[C@@](C)(O)[C@H](C)C1=[N+]([O-])CCCC1</smiles>

6: Ketonitrone

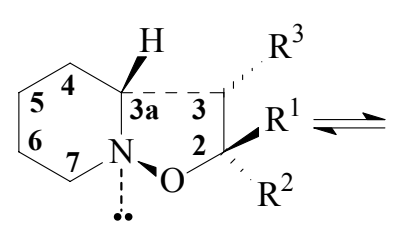
trans 5 Major or exlusive

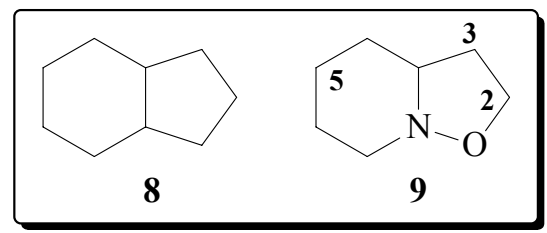

\section{Scheme 1}




\section{Results and Discussion}

The nitrogen inversions barriers are determined using NMR band shape analysis. Slow nitrogen inversion in most of the isoxazolidines has been observed to give broadened peaks in ${ }^{1} \mathrm{H}$ and ${ }^{13} \mathrm{C}$ spectra recorded above ambient temperatures. On lowering the temperature, the spectral lines become sharper and show two distinct forms of the compound. The ${ }^{13} \mathrm{C}$ chemical shifts in $\mathrm{CDCl}_{3}$ and $\mathrm{CD}_{3} \mathrm{OD}$ were assigned on the basis of DEPT experiment results, general chemical shifts arguments and consideration of substituent effects, and are given in Table 1.

Table 1. ${ }^{13} \mathrm{C}$ NMR chemical shifts of $\mathbf{3}$ and $\mathbf{4}$ studied in $\mathrm{CDCl}_{3}{ }^{a}$ or $\mathrm{CD}_{3} \mathrm{OD}^{b}$ at $-30^{\circ} \mathrm{C}^{c}$

\begin{tabular}{|c|c|c|c|c|c|c|c|c|}
\hline Compound & Invertomer $^{d}$ & $\mathrm{C}-2$ & C-3 & $\mathrm{C}-3 \mathrm{a}$ & $\mathrm{C}-4$ & $\mathrm{C}-5$ & C-6 & $\mathrm{C}-7$ \\
\hline \multirow{2}{*}{$3 \mathbf{a}^{a, e}\{$} & Major (C) & 77.25 & 36.05 & 58.95 & 27.75 & 35.43 & 26.96 & 48.65 \\
\hline & Minor (A) & 76.15 & 39.86 & 62.96 & 30.65 & 37.66 & 26.17 & 52.37 \\
\hline & Major (C) & 78.86 & 38.31 & 60.33 & 28.71 & 35.27 & 28.09 & 49.17 \\
\hline & Minor (A) & 77.35 & 40.30 & 64.18 & 29.25 & 36.24 & 26.70 & 53.03 \\
\hline $4 a^{a, e}$ & (A) & 76.54 & 41.44 & 65.37 & 30.60 & 39.57 & 27.44 & 53.61 \\
\hline \multirow{2}{*}{$3 \mathbf{b}^{a}$} & major $(\mathbf{C})$ & 78.74 & 38.33 & 59.54 & 27.38 & 35.61 & 26.89 & 48.73 \\
\hline & $\operatorname{minor}(\mathbf{A})$ & 77.71 & 42.63 & 63.59 & 30.54 & 37.31 & 25.97 & 52.37 \\
\hline \multirow[t]{2}{*}{$\mathbf{3} \mathbf{b}^{b}$} & major $(\mathbf{C})$ & 80.58 & 38.98 & 61.21 & 28.75 & 36.18 & 28.25 & 49.44 \\
\hline & $\operatorname{minor}(\mathbf{A})$ & 79.16 & 44.12 & 64.44 & 31.30 & 38.28 & 26.60 & 53.00 \\
\hline $4 b^{a, e}$ & (A) & 78.17 & 42.65 & 65.91 & 31.82 & 41.46 & 27.54 & 53.81 \\
\hline \multirow{2}{*}{$3 c^{a, e}\{$} & Major (A) & 79.92 & 44.30 & 63.33 & 30.37 & 37.05 & 25.58 & 52.48 \\
\hline & $\operatorname{Minor}(\mathbf{C})$ & 84.14 & 39.95 & 59.38 & 29.89 & 35.55 & 27.01 & 49.57 \\
\hline \multirow{2}{*}{$3 c^{b}$} & Major (A) & 81.29 & 45.13 & 64.76 & 30.99 & 38.18 & 26.59 & 53.08 \\
\hline & Minor (C) & 85.65 & 39.46 & 60.72 & 28.32 & 36.31 & 28.32 & 50.51 \\
\hline $4 c^{a}$ & (A) & 80.50 & 44.36 & 65.80 & 31.35 & 41.21 & 27.16 & 53.75 \\
\hline \multirow{2}{*}{$3 \mathrm{~d}^{a, e}\{$} & Major (A) & 75.21 & 56.45 & 65.88 & 27.59 & 36.94 & 25.44 & 52.30 \\
\hline & Minor $(\mathbf{C})$ & 75.66 & 52.46 & 59.19 & 26.50 & 36.18 & 26.73 & 47.87 \\
\hline $\mathbf{3} \mathbf{d}^{b, f}$ & Major (A) & 76.79 & 57.16 & 67.33 & 28.86 & 38.13 & 26.44 & 52.40 \\
\hline
\end{tabular}

${ }^{a} \mathrm{NMR}$ measured in $\mathrm{CDCl}_{3} .{ }^{b} \mathrm{NMR}$ measured in $\mathrm{CD}_{3} \mathrm{OD}$. ${ }^{c}$ Except that the NMR of 3a, 4a and $\mathbf{4 b}$ were measured in $\mathrm{CDCl}_{3}$ at $+25^{\circ} \mathrm{C}$. ${ }^{d}$ Refers to invertomer $\mathbf{A}$ or $\mathbf{C}$ in Scheme 2. ${ }^{e}$ Data taken from Reference 3. ${ }^{f}$ Even though the ${ }^{1} \mathrm{H}$ NMR spectrum revealed the presence of the minor invertomer $(\sim 7 \%)$ (Table 1), we were unable to locate accurately the signals of the minor form in the ${ }^{13} \mathrm{C}$ NMR spectrum.

At ambient temperature, the ${ }^{1} \mathrm{H}$ NMR spectra of these compounds show well separated signals for the two invertomers in toluene- $\mathrm{d}_{6}$ as well as in $\mathrm{CDCl}_{3}$ or $\mathrm{CD}_{3} \mathrm{OD}$. Integration of the 
relevant peaks gives the population trends in these systems (Tables 2 and 3). The proton spectra in toluene- $\mathrm{d}_{6}$ and $\mathrm{CD}_{3} \mathrm{OD}$ were used in the calculation of the nitrogen inversion barriers in all compounds. The solvent $\mathrm{CDCl}_{3}$ was avoided since it was found that some of the compounds deteriorated at higher temperatures $\left(\sim 75^{\circ} \mathrm{C}\right)$ in the halogen containing solvent. The complete band shape analysis yielded the rate constants and the free energy of activation was calculated using Eyring equation. The activation parameters $\Delta \mathrm{H}^{\ddagger}$ and $\Delta \mathrm{S}^{\neq}$were calculated from plots of $\ln (\mathrm{k} / \mathrm{T}) v s .1 / \mathrm{T}$. It is well known ${ }^{10}$ that NMR band shape fitting frequently gives rather large but mutually compensating errors in $\Delta \mathrm{H}^{\neq}$and $\Delta \mathrm{S}^{\neq}$and as such their values are not reported here. However, band shape fitting is viewed as a method of getting rather accurate values of $\Delta \mathrm{G}^{\neq}$ (probably within $\pm 0.3 \mathrm{~kJ} / \mathrm{mol}$ ) in the vicinity of the coalescence temperature. The $\Delta \mathrm{G}^{\neq}$values calculated at $40^{\circ} \mathrm{C}$ are reported in Table 2 , along with the invertomer ratios and $\Delta \mathrm{G}^{\mathrm{o}}$ values.

Table 2. Free energy of activation $\left(\Delta \mathrm{G}^{\ddagger}\right)$ for nitrogen inversion, ratio of the invertomers, and standard free energy change $\left(\Delta \mathrm{G}^{\mathrm{o}}\right)$ for major $\rightleftharpoons$ minor isomerization in toluene- $\mathrm{d}_{8}$ and $\mathrm{CD}_{3} \mathrm{OD}$

\begin{tabular}{|c|c|c|c|c|c|c|}
\hline \multirow[b]{2}{*}{ Compound } & \multicolumn{3}{|c|}{ Toluene- $\mathrm{d}_{8}$} & \multicolumn{3}{|c|}{$\mathrm{CD}_{3} \mathrm{OD}$} \\
\hline & $\begin{array}{c}\Delta \mathrm{G}^{f} \\
(\mathrm{~kJ} / \mathrm{mol})^{\mathrm{a}}\end{array}$ & $\begin{array}{c}\text { Invertomer } \\
\text { Ratio }^{b}\end{array}$ & $\begin{array}{c}\Delta \mathrm{G}^{\mathrm{o}} \\
(\mathrm{kJ} / \mathrm{mol})^{\mathrm{b}}\end{array}$ & $\begin{array}{c}\Delta \mathrm{G}^{\neq} \\
(\mathrm{kJ} / \mathrm{mol})^{\mathrm{a}}\end{array}$ & $\begin{array}{c}\text { Invertomer } \\
\text { Ratio }\end{array}$ & $\begin{array}{c}\Delta \mathrm{G}^{\mathrm{o}} \\
(\mathrm{kJ} / \mathrm{mol})^{\mathrm{b}}\end{array}$ \\
\hline $3 \mathbf{a}$ & 67.9 & $50: 50$ & +0 & 72.3 & $70: 30$ & +1.9 \\
\hline $4 a$ & - & $100 *$ & - & - & $100 *$ & - \\
\hline $3 b$ & 68.3 & 58: 42 & +0.78 & 69.5 & $78: 22$ & +2.8 \\
\hline $4 b$ & - & $100 *$ & - & - & $100 *$ & - \\
\hline $3 c$ & 62.1 & $75: 25$ & +2.7 & 67.8 & $57: 43$ & +0.60 \\
\hline $4 c$ & - & $100 *$ & - & - & $100 *$ & - \\
\hline $3 d$ & 65.2 & 81:19 & +3.3 & 67.3 & $93: 7$ & +5.9 \\
\hline
\end{tabular}

${ }^{\mathrm{a}} \mathrm{At}+40{ }^{\circ} \mathrm{C} .{ }^{\mathrm{b}}$ At $0{ }^{\circ} \mathrm{C}$. $*$ The other isomer was not detected.

For the $6 / 5$ fused compound $\mathbf{8}$, the carbocyclic counterpart of the heterocycle $\mathbf{9}$, the $\Delta \mathrm{G}^{\mathrm{o}}$ value of $2.09 \mathrm{~kJ} / \mathrm{mol}$ at $25^{\circ} \mathrm{C}$ favours the trans- over the cis-fused isomer (Scheme 1). ${ }^{11}$ Both the parent heterocycle 9 and its derivatives 5 having substituents at 2- and 3-positions are also reported to favour the trans invertomers. ${ }^{7,12}$ The isoxazolidines $\mathbf{3}$ and $\mathbf{4}$, having a substituent at $\mathrm{C}(5)$ of the six-membered ring, can, in principle, exist in three different chair conformations, the trans isomer $\mathbf{A}$ and the cis pair $\mathbf{B}$ and $\mathbf{C}$ (Scheme 2). While the cis pair is in rapid equilibrium by chair inversion $\left(\mathbf{C}_{\mathbf{I}}\right)$, one of the cis conformer $\mathbf{B}$ is converted into the trans conformer by a relatively slow nitrogen inversion process $\left(\mathbf{N}_{\mathbf{I}}\right)$. To our knowledge, no previous attempt has been made to measure the barriers to nitrogen inversion in these systems having substituents at both the five- as well as six-membered rings. The NMR spectra, both ${ }^{1} \mathrm{H}$ and ${ }^{13} \mathrm{C}$, for some of the 
compounds show peaks due to two distinct isomers, a major and a minor invertomer. With respect to the six-membered ring, both the isomers trans-fused $\mathbf{A}$ and cis-fused $\mathbf{C}$ of $\mathbf{3}$ has one axial substituent at $\mathrm{C}(5)$ and $\mathrm{C}(3 \mathrm{a})$, respectively, while the invertomer cis-fused $\mathbf{B}$ has two energetically destabilizing axial substituents at $\mathrm{C}(5)$ and $N$. As such compound $\mathbf{3}$ is expected to remain as $\mathbf{A}$ and/or $\mathbf{C}$. For the same reason as discussed above, the isoxazolidine $\mathbf{4}$ should have overwhelming preference for the trans-fused invertomer $\mathbf{A}$ since it is free of any destabilizing axial group. The conformer 4-C having two axial substituents is anticipated to be the least favoured.

Table 3. Ratio of the invertomers of $\mathbf{3 , 4}$ and $\mathbf{5}$ in $\mathrm{CDCl}_{3}$ and $\mathrm{CD}_{3} \mathrm{OD}$

\begin{tabular}{|c|c|c|c|}
\hline \multirow[t]{2}{*}{ Compound } & \multirow[t]{2}{*}{ Invertomer(s) ${ }^{\mathrm{a}}$} & \multicolumn{2}{|c|}{ Invertomer ration } \\
\hline & & $\mathrm{CDCl}_{3}$ & $\mathrm{CD}_{3} \mathrm{OD}$ \\
\hline $\mathbf{3 a}$ & trans-A /cis-C & $42: 58$ & $30: 70$ \\
\hline $4 \mathbf{a}$ & trans-A & $100: \sim 0$ & $100: \sim 0$ \\
\hline $5 a^{b}$ & trans/cis & $70: 30$ & - \\
\hline $\mathbf{3 b}$ & trans-A /cis-C & $45: 55$ & $22: 78$ \\
\hline $4 b$ & trans-A & $100: \sim 0$ & $100: \sim 0$ \\
\hline $5 \mathbf{b}^{\mathrm{b}}$ & trans/cis & $78: 22$ & $71: 29$ \\
\hline $3 c$ & $\operatorname{trans}-\mathbf{A} /$ cis- $\mathbf{C}$ & $70: 30$ & $57: 43$ \\
\hline $4 c$ & trans-A & $100: \sim 0$ & $100: \sim 0$ \\
\hline $5 c^{b}$ & trans/cis & $87: 13$ & - \\
\hline 3d & $\operatorname{trans}-\mathbf{A} / c i s-\mathbf{C}$ & $80: 20$ & $93: 7$ \\
\hline $5 d^{b}$ & trans/cis & $100: \sim 0$ & - \\
\hline
\end{tabular}

${ }^{a}$ Refers to invertomer $\mathbf{A}$ or $\mathbf{C}$ in Scheme 2; ${ }^{b}$ Data taken from Reference 7.

A comparison between compound $\mathbf{3} \mathbf{b}$ and $\mathbf{5 b}$, both having a phenyl group at $\mathrm{C}(2)$, may be helpful in identifying the stereochemistry of the ring fusion in the former. Compound $\mathbf{5 b}$ in $\mathrm{CDCl}_{3}$ is known to favour the trans-fused isomer over its cis form (Scheme 1). ${ }^{7}$ Since the axially disposed ester substituent at $\mathrm{C}(5)$ of $\mathbf{3}$ is expected to destabilize its trans $\mathbf{3}-\mathbf{A}$ as well as cis $\mathbf{3}-\mathbf{B}$; the relative proportion of $\mathbf{c i s - 3 - C}$ is anticipated to increase in compare to that of compound $\mathbf{5}$ (Scheme 2). As evident from Table 3, this is indeed the case; the cis-isomer becomes the major invertomers for $\mathbf{3 a}$ and $\mathbf{3 b}$, while its relative proportion increases for $\mathbf{3 c}$ and $\mathbf{3 d}$ in compare to $\mathbf{5 c}$ and $\mathbf{5 d}$. The correctness of assigning the configuration is supported by information gathered from several experimental data. The x-ray diffraction study and low temperature $\left(-90^{\circ} \mathrm{C}\right)$ proton NMR study have shown the cis-C conformation (Scheme 2) of $\mathbf{3 b}$ as the sole/or major form in the solid state as well as in the solution. ${ }^{3}$ The $\mathrm{C}(2) \mathrm{H}$ of the cis invertomers of $\mathbf{5}$ is known to appear at 
higher frequency compared to the trans invertomers. ${ }^{13}$ This was indeed found to be the case for the current compounds $\mathbf{3}$ and $\mathbf{4}$ in $\mathrm{CDCl}_{3}$; the $\mathrm{C}(2) \mathrm{H}$ of the cis- $\mathbf{C}$ invertomers invariably appeared at higher frequency compared to their trans-A isomers (Table 4). The axially disposed $\mathrm{C}(3 \mathrm{a}) \mathrm{H}$ of trans-A, as expected, appeared at lower frequency in comparison to the corresponding equatorially disposed proton of cis-C. Similar trend is observed in the proton chemical shifts in $\mathrm{CD}_{3} \mathrm{OD}$ (Experimental).
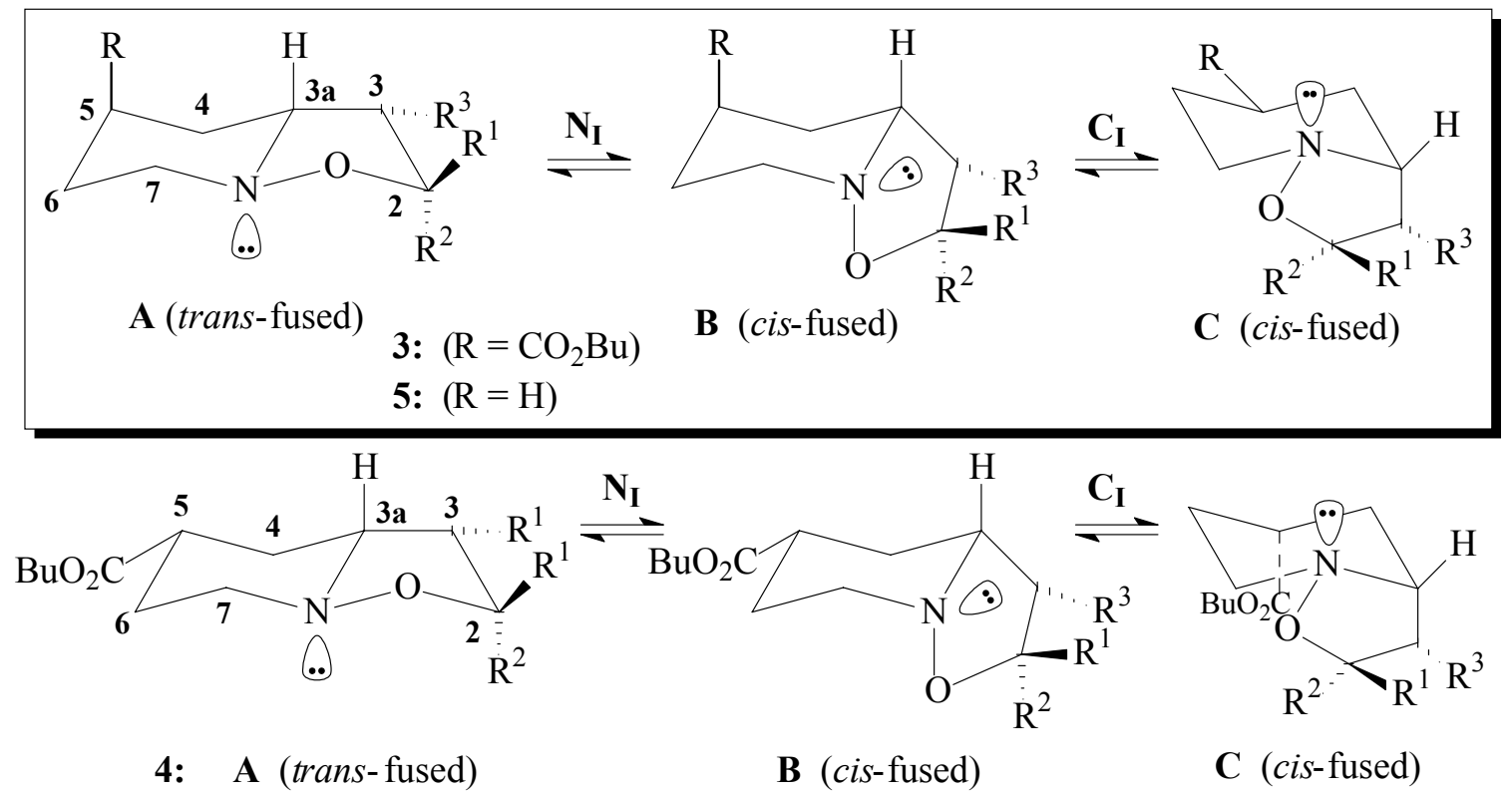

Favoured

\section{Scheme 2}

The ${ }^{13} \mathrm{C}$ chemical shifts of the compounds were assigned on the basis of the published data on indolizidine, general chemical shifts arguments and consideration of substituent effects. ${ }^{14}$ The axial substituent at $\mathrm{C}(3 \mathrm{a})$ of the cis conformer 3-C will have $\gamma$-gauche interactions with $\mathrm{C}(5)$ and $\mathrm{C}(7)$ and as such these carbon signals are expected to be shielded in comparison to the trans isomer 3-A (Scheme 2). As evident from Table 1, the $\mathrm{C}(7)$ of the invertomers cis- $\mathbf{C}$ of the compounds 3 is shifted to lower frequency by almost $4 \mathrm{ppm}$ in $\mathrm{CDCl}_{3}$ as well as in $\mathrm{CD}_{3} \mathrm{OD}$. Generally the $\mathrm{C}(5)$ is also shielded by around $2 \mathrm{ppm}$. Similar trend is observed for the corresponding shifts of $\mathbf{3 c}$ in $\mathrm{CDCl}_{3}$. Note that the $\mathrm{C}(3 \mathrm{a})$ of the invertomers cis- $\mathbf{C}$ of all the compounds in series 3 appeared at lower frequency by around $4 \mathrm{ppm}$, whereas the $\mathrm{C}(2)$ signals invariably appeared at higher frequency in compare to invertomers $\mathbf{A}$. Thus, while the cis-ring fusion is favoured over the trans-ring for compound $\mathbf{3 a}$ and $\mathbf{3 b}$, the opposite is true in the case of the corresponding $\mathbf{5 a}$ and $\mathbf{5 b}$ (Table 3).

Where only one invertomer is observed as in series 4, the $\mathrm{C}(2), \mathrm{C}(3 \mathrm{a})$ and $\mathrm{C}(7)$ chemical shifts match those of the trans-fused 3-A invertomers, and we can therefore conclude that these compounds exist almost exclusively in the trans conformation. The presence of 1,3-diaxial 
interaction exclude the participation of conformer 4-C in the equilibration process (Scheme 2). In the absence of $\mathbf{B} \rightleftharpoons \mathbf{C}$ equilibration, the stabilization arising out of entropy gain will be lost; as such the all equatorial trans-invertomer $\mathbf{A}$ is expected to be overwhelmingly favoured over cis-B. It corroborated the experimental findings: all the isoxazolidines in the series $\mathbf{4}$ remained as the sole conformers in solution.

Table 4. ${ }^{1} \mathrm{H}$ NMR chemical shifts of $\mathrm{C}(2) \mathrm{H}$ and $\mathrm{C}(3 \mathrm{a}) \mathrm{H}$ signals of the compounds studied in $\mathrm{CDCl}_{3}$

\begin{tabular}{|c|c|c|c|c|}
\hline \multirow[t]{3}{*}{ Isoxazolidine } & \multicolumn{2}{|c|}{$\mathrm{C}(2) \mathrm{H}$} & \multicolumn{2}{|c|}{$\mathrm{C}(3 \mathrm{a}) \mathrm{H}$} \\
\hline & cis- $\mathbf{C}^{a}$ & trans $-\mathbf{A}^{a}$ & cis- $\mathbf{C}^{a}$ & trans $-\mathbf{A}^{a}$ \\
\hline & $\delta(\mathrm{ppm})$ & $\delta(\mathrm{ppm})$ & $\delta(\mathrm{ppm})$ & $\delta(\mathrm{ppm})$ \\
\hline $3 a$ & 4.39 & 4.02 & 3.61 & 3.35 \\
\hline $4 a$ & $-^{\mathrm{b}}$ & 4.08 & $-^{\mathrm{b}}$ & 3.48 \\
\hline $3 b$ & 5.40 & 5.02 & 3.87 & 3.44 \\
\hline $4 b$ & $-^{\mathrm{b}}$ & 5.08 & $-^{\mathrm{b}}$ & 3.60 \\
\hline $3 c$ & $-{ }^{\mathrm{c}}$ & $-^{\mathrm{c}}$ & 3.80 & 3.47 \\
\hline $4 c$ & $--^{c}$ & $-{ }^{c}$ & $-^{\mathrm{b}}$ & 3.57 \\
\hline $3 d$ & 4.85 & 4.54 & 3.82 & 3.47 \\
\hline
\end{tabular}

${ }^{\mathrm{a}}$ Type of invertomers (Scheme 2). ${ }^{\mathrm{b}}$ No minor invertomer. ${ }^{\mathrm{c}}$ No $\mathrm{C}(2) \mathrm{H}$ (Scheme 1).

The nitrogen inversion barrier is expected to be high when an oxygen atom is directly attached to the nitrogen as in isoxazolidines. ${ }^{6,7}$ The inversion barriers observed in the isoxazolidines 3 in toluene- $\mathrm{d}_{6}$ are in the relatively narrow range $62.1-68.3 \mathrm{~kJ} \mathrm{~mol}^{-1}$. This is expected since the steric requirements to attain the $\mathrm{sp}^{2}$ hybridized transition state (through which the nitrogen inversion occurs) remains more or less similar as the substituents in the immediate vicinity of nitrogen (i.e. $\alpha$-positions to nitrogen) remains the same in all the isoxazolidines. The inversion barrier increases to some extent in hydrogen bonding solvent $\mathrm{CD}_{3} \mathrm{OD}$. Any increase in the barrier in cyclic system is attributed to the extra energy required for breaking of H-bonding prior to inversion. ${ }^{6}$ The population of the cis-invertomers is higher in $\mathrm{CD}_{3} \mathrm{OD}$ than in $\mathrm{CDCl}_{3}$ (Table 2) for the ioxazolidines $\mathbf{3 a}, \mathbf{3 b}$ and $\mathbf{3 c}$, indicating that the invertomer is more stabilized by hydrogen bonding than the trans invertomer. However, the compound 3d behaves the opposite way.

The NMR study has been successful in studying the nitrogen inversion process and the effect of substitution at $\mathrm{C}(5)$ on the stereochemistry of the ring fusion of this important class of bicyclic compounds containing piperidine as well as isoxazolidine moiety. A judicious choice of substituent(s) in the isoxazolidine ring would tilt the population ratio either in favour of cis- or 
trans-fused rings. The information would lead to better utilization of the compounds as discussed for the per-acid induced ring opening reactions.

\section{Experimental Section}

\section{Compounds studied}

A total of 7 compounds have been studied in the current work. The structures of these compounds $\mathbf{3}$ and $\mathbf{4}$ are given in Scheme 1 .

\section{Physical methods}

The variable temperature ${ }^{1} \mathrm{H}$ NMR spectra were recorded on a JEOL Lambda NMR spectrometer operating at $500.0 \mathrm{MHz}$. Most of the compounds were studied as $25 \mathrm{mg} / \mathrm{cm}^{3}$ solutions in $\mathrm{CDCl}_{3}$, toluene- $\mathrm{d}_{8}$ and $\mathrm{CD}_{3} \mathrm{OD}$ with TMS as internal standard. Multiplicities of the carbons were determined using DEPT experiments.

\section{Preparation of compounds 3 and 4}

The isoxazolidines (3 and $\mathbf{4}) \mathbf{a}-\mathbf{d}$ were prepared using procedure as described [3]. ${ }^{3}$ Thus, 1,3dipolar cycloaddition reaction of 4-butyloxycarbonyl-3,4,5,6-tetrahydropyridine 1-oxide (1) with some mono- and di-substitutd alkenes $\mathbf{2}$ alkenes afforded the isomeric isoxazolidines $\mathbf{3}$ and $\mathbf{4}$ which were separated as described ${ }^{3}$ (Scheme 1). The configuration of the isoxazolidines 3a-d and 4a-c has been assigned by means of NMR spectroscopic and X-ray analysis. ${ }^{3}$ For conformational analysis, the ${ }^{13} \mathrm{C}$ data are summarized in Table 1 . The low temperature ${ }^{1} \mathrm{H}$ and ${ }^{13} \mathrm{C} \mathrm{NMR}$ data of some these compounds measured in $\mathrm{CDCl}_{3}$ are taken from reference 3; additional data in $\mathrm{CDCl}_{3}$ and $\mathrm{CD}_{3} \mathrm{OD}$ are given below.

\section{Compound 3a}

The ${ }^{1} \mathrm{H}$ spectrum in $\mathrm{CDCl}_{3}$ at $+25{ }^{\circ} \mathrm{C}$ or $-30^{\circ} \mathrm{C}$ revealed ${ }^{3}$ the presence of two invertomers by displaying $\mathrm{C}(2) \mathrm{H}$ proton signals at $\delta 4.39$ (major) and 4.02 (minor) ppm in a ratio of 58:42. The other non-overlapping signals were displayed at $\delta 3.61$ (major) and $3.35 \mathrm{ppm}$ (minor). The ${ }^{1} \mathrm{H}$ or ${ }^{13} \mathrm{C}$ NMR spectra at $-30^{\circ} \mathrm{C}$ were found to be similar to those at $+25{ }^{\circ} \mathrm{C}$.

In $\mathrm{CD}_{3} \mathrm{OD}\left(-40^{\circ} \mathrm{C}\right)$ the ${ }^{1} \mathrm{H} \mathrm{NMR}$ spectrum revealed several nonoverlapping signals indicating the presence of the major and minor isomers in a ratio of $70: 30$. The $\mathrm{C}(2) \mathrm{H}$ appeared at $\delta 4.43$ (major) and 4.00 (minor). The $\mathrm{OCH}_{2}$ protons appeared at $\delta 4.10(\mathrm{t}$, minor) and 4.05 (t, major), while the $\mathrm{C}(3 \mathrm{a}) \mathrm{H}$ appeared at $\delta 3.25$ (minor) and 3.52 (major) ppm.

Major invertomer. $\delta_{\mathrm{C}}\left(\mathrm{CD}_{3} \mathrm{OD},-40{ }^{\circ} \mathrm{C}\right) 14.25,14.66,20.23,23.91,28.09,28.71,29.37,31.71$, $35.27,36.47,38.31,49.17,60.33,65.43,78.86,175.79$.

Minor invertomer. $\delta_{\mathrm{C}}\left(\mathrm{CD}_{3} \mathrm{OD},-40{ }^{\circ} \mathrm{C}\right) 14.25,14.66,20.33,23.91,26.70,29.20,29.25,31.31$, $35.43,36.24,40.30,53.03,64.18,65.53,77.35,175.07$.

\section{Compound $4 \mathbf{a}$}

The ${ }^{1} \mathrm{H}$ and ${ }^{13} \mathrm{C}$ NMR spectra in $\mathrm{CDCl}_{3}$ (or $\mathrm{CD}_{3} \mathrm{OD}$ ) at $+25{ }^{\circ} \mathrm{C}$ or $-30{ }^{\circ} \mathrm{C}$ indicated the presence of a single invertomer. ${ }^{3}$ 


\section{Compound 3b}

The major and minor invertomer at $+25^{\circ} \mathrm{C}$ was found ${ }^{3}$ to be in a ratio of 55:45 as determined by integration of the $\mathrm{C}(2) \mathrm{H}$. (The ratio becomes $60: 40$ at $-40{ }^{\circ} \mathrm{C}$ ). The ${ }^{1} \mathrm{H}$ spectra at $+25^{\circ} \mathrm{C}$ and $40^{\circ} \mathrm{C}$ remained sharp and almost identical.

Major invertomer. $\delta_{\mathrm{C}}\left(\mathrm{CDCl}_{3},-30^{\circ} \mathrm{C}\right) 13.84,19.07,26.89,27.38,30.35,35.61,38.33,48.73$, 59.54, 64.66, 78.74, 126.36 (2C), 127.72, 128.45 (2C), 141.79, 174.74.

Minor invertomer. $\quad \delta_{\mathrm{C}}\left(\mathrm{CDCl}_{3},-30^{\circ} \mathrm{C}\right) 13.84,19.17,25.97,30.39,30.54,37.31,42.63,52.37$, $63.59,64.70,77.71,126.90$ (2C), 127.92, 128.45 (2C), 140.90, 174.29.

In $\mathrm{CD}_{3} \mathrm{OD}\left(-40^{\circ} \mathrm{C}\right)$ the ${ }^{1} \mathrm{H}$ NMR spectrum revealed several nonoverlapping minor signals indicating the presence of the major/minor invertomers of $\mathbf{3 b}$ in a ratio of 78:22. The $\mathrm{C}(2) \mathrm{H}$ signals appeared at $\delta 4.99$ (dd, $J, 4.3,9.5 \mathrm{~Hz}$, minor) and 5.40 (dd, $J, 4.0 \mathrm{~Hz}$, the other $J$ value can not be measured due to overlap with the solvent peak, major). The $\mathrm{C}(3 \mathrm{a}) \mathrm{H}$ appeared as multiplets at $\delta 3.88$ (major) and 3.38 ppm (minor).

Major invertomer. $\delta_{\mathrm{C}}\left(\mathrm{CD}_{3} \mathrm{OD},-40^{\circ} \mathrm{C}\right) 14.26,20.28,28.25,28.75,31.76,36.18,38.98,49.44$, 61.21, 65.54, 80.58, 127.78 (2C), 128.99, 129.59 (2C), 143.23, 175.86.

Minor invertomer. $\delta_{\mathrm{C}}\left(\mathrm{CD}_{3} \mathrm{OD},-40^{\circ} \mathrm{C}\right) \delta_{\mathrm{C}}\left(\mathrm{CD}_{3} \mathrm{OD},-40^{\circ} \mathrm{C}\right) 14.26,20.41,26.60,31.30,31.76$, $38.28,44.12,53.00$, 64.44, 65.66, 79.16, 127.78 (2C), 129.04, 129.59 (2C), 142.62, 175.30.

Compound 4b. The sharp ${ }^{1} \mathrm{H}$ and ${ }^{13} \mathrm{C}$ signals at $+25^{\circ} \mathrm{C}$ or $-30{ }^{\circ} \mathrm{C}$ indicated the presence of a single invertomer.

A single invertomer. $\delta_{\mathrm{H}}\left(\mathrm{CDCl}_{3},-30^{\circ} \mathrm{C}\right) 0.94(3 \mathrm{H}, \mathrm{t}, J 7.4 \mathrm{~Hz}), 1.39(2 \mathrm{H}, \mathrm{m}), 1.62(2 \mathrm{H}, \mathrm{m}), 1.69$ $(1 \mathrm{H}, \mathrm{m}), 1.94(1 \mathrm{H}, \mathrm{m}), 2.10-2.75(7 \mathrm{H}, \mathrm{m}), 3.60(1 \mathrm{H}, \mathrm{m}), 4.09(2 \mathrm{H}, \mathrm{t}, J 6.6 \mathrm{~Hz}), 5.08(1 \mathrm{H}, \mathrm{dd}, J$ $4.3,9.5 \mathrm{~Hz}), 7.34(5 \mathrm{H}, \mathrm{m})$.

The ${ }^{1} \mathrm{H}$ spectra in $\mathrm{CD}_{3} \mathrm{OD}$ at +25 and $-30^{\circ} \mathrm{C}$ were almost identical and indicated the presence of a single invertomer.

Compound 3c. The ${ }^{1} \mathrm{H}$ spectrum of $3 \mathbf{c}$ in $\mathrm{CDCl}_{3}$ at $0^{\circ} \mathrm{C}$ and $-30^{\circ} \mathrm{C}$ revealed ${ }^{3}$ the presence of two invertomers in a ratio of around 70:30. The ${ }^{1} \mathrm{H}$ NMR spectrum of $3 \mathbf{c}$ in $\mathrm{CD}_{3} \mathrm{OD}\left(-40^{\circ} \mathrm{C}\right)$ revealed the presence of several nonoverlapping signals indicating the presence of the major and minor invertomers in a ratio of 57:43. The $\mathrm{CO}_{2} \mathrm{Me}$ methyl singlets appeared at $\delta 3.72$ (major) and 3.74 (minor) and the corresponding $\mathrm{C}(2) \mathrm{Me}$ singlets appeared at $\delta 1.41$ (major) and $1.45 \mathrm{ppm}$ (minor).

Major invertomer. $\delta_{\mathrm{C}}\left(\mathrm{CD}_{3} \mathrm{OD},-30^{\circ} \mathrm{C}\right) 14.26,20.37,24.74,26.59,30.99,31.76,38.18,45.13$, 53.08, 53.30, 64.76, 65.63, 81.29, 175.17, 176.91.

Minor invertomer. $\delta_{\mathrm{C}}\left(\mathrm{CD}_{3} \mathrm{OD},-30^{\circ} \mathrm{C}\right) 14.26,20.28,25.76,28.32,30.99,31.76,36.31,39.46$, $50.51,53.30,60.72,65.56,85.65,175.71,176.33$.

Compound 4c. The spectra in $\mathrm{CDCl}_{3}$ at $+25^{\circ} \mathrm{C}^{3}$ as well as $-30^{\circ} \mathrm{C}$ have sharp and more or less similar signals, and indicated the absence of the minor invertomer. The ${ }^{1} \mathrm{H}$ spectra in $\mathrm{CD}_{3} \mathrm{OD}$ at $+25^{\circ} \mathrm{C}$ and $-30^{\circ} \mathrm{C}$ were also almost identical and indicated the presence of a single invertomer. 
A single invertomer. $\delta_{\mathrm{H}}\left(\mathrm{CDCl}_{3},-30^{\circ} \mathrm{C}\right) 0.94(3 \mathrm{H}, \mathrm{t}, \mathrm{J} 7.3 \mathrm{~Hz}), 1.37(2 \mathrm{H}$, hext, $J 7.5 \mathrm{~Hz}), 1.52$ $(3 \mathrm{H}, \mathrm{s}), 1.61(3 \mathrm{H}, \mathrm{m}), 1.92(1 \mathrm{H}, \mathrm{m}), 2.08(1 \mathrm{H}, \mathrm{m}), 2.21(2 \mathrm{H}, \mathrm{m}), 2.38(2 \mathrm{H}, \mathrm{m}), 2.46(1 \mathrm{H}, \mathrm{m})$, $2.54(1 \mathrm{H}, \mathrm{m}), 3.57(1 \mathrm{H}, \mathrm{td}, J 3.5,9.5 \mathrm{~Hz}), 3.81(3 \mathrm{H}, \mathrm{s}), 4.06(2 \mathrm{H}, \mathrm{t}, J 6.8) ; \delta_{\mathrm{C}}\left(\mathrm{CDCl}_{3},-30^{\circ} \mathrm{C}\right)$ $13.74,19.13,24.50,27.16,30.65,31.35,41.21,44.36,52.48,53.75,64.33,65.80,80.50,173.73$, 175.20 .

Compound 3d. The major and minor invertomers of $\mathbf{3 d}$ at $+25^{\circ} \mathrm{C}$ were found to be in a ratio of $80: 20$ as determined by integration of the $\mathrm{C}(2) \mathrm{H}$ which appeared at $\delta 4.54$ (quint, major) and 4.85 (br, minor). The ratio becomes $90: 10$ and $81: 19$ at $-40^{\circ} \mathrm{C}$ and $0^{\circ} \mathrm{C}$, respectively.

Major invertomer. $\delta_{\mathrm{H}}\left(\mathrm{CDCl}_{3},-30^{\circ} \mathrm{C}\right) 0.95(3 \mathrm{H}, \mathrm{t}, J 7.4 \mathrm{~Hz}), 1.35(3 \mathrm{H}, \mathrm{d}, J 6.4 \mathrm{~Hz}), 1.37(2 \mathrm{H}$, m), $1.53(1 \mathrm{H}, \mathrm{m}), 1.65(2 \mathrm{H}, \mathrm{m}), 1.90(1 \mathrm{H}, \mathrm{m}), 2.32(1 \mathrm{H}, \mathrm{m}), 2.48(1 \mathrm{H}, \mathrm{m}), 2.53(1 \mathrm{H}, \mathrm{m}), 2.60$ $(1 \mathrm{H}, \mathrm{m}), 2.79(1 \mathrm{H}, \mathrm{m}), 2.96(1 \mathrm{H}, \mathrm{dd}, J 4.6,6.5 \mathrm{~Hz}), 3.47(1 \mathrm{H}, \mathrm{m}), 3.77(3 \mathrm{H}, \mathrm{s}), 4.10(1 \mathrm{H}, \mathrm{m})$, $4.16(1 \mathrm{H}, \mathrm{m}), 4.54(1 \mathrm{H}$, quint, $J 5.8 \mathrm{~Hz})$.

Minor invertomer. The $\mathrm{C}(2) \mathrm{H}$ and $\mathrm{C}(3 \mathrm{a}) \mathrm{H}$ of minor invertomer appeared at $\delta 4.85$ and 3.82 ppm, respectively. The non overlapping carbon signals were as follows: $\delta_{\mathrm{C}}\left(\mathrm{CDCl}_{3},-30^{\circ} \mathrm{C}\right)$ 13.87, 19.13, 19.34, 26.50, 26.73, 28.64, 36.18, 47.87, 52.30, 52.46, 59.19, 64.56, 75.66.

The ${ }^{1} \mathrm{H}$ NMR spectrum in $\mathrm{CD}_{3} \mathrm{OD}\left(-30^{\circ} \mathrm{C}\right)$ revealed several nonoverlapping signals indicating the presence of the major and minor isomers in a ratio of 93:7. The $\mathrm{C}(2) \mathrm{H}$ appeared at $\delta 4.85$ (minor), and 4.45 ppm (major). Minor signals were not visible in ${ }^{13} \mathrm{C}$.

Major invertomer. $\delta_{\mathrm{C}}\left(\mathrm{CD}_{3} \mathrm{OD},-30^{\circ} \mathrm{C}\right) 14.26,19.33,20.37,26.44,28.86,31.74,38.13,52.40$, 53.44, 57.16, 65.71, 67.33, 76.79, 173.21, 174.95 .

\section{Inversion barrier calculations}

Simulations of exchange-affected proton spectra for all compounds were carried out using a computer program $\mathrm{AXEX}^{15}$, corresponding to a two non coupled sites exchange with unequal populations. For 3a in toluene- $\mathrm{d}_{6}$, signals at $\delta 3.00$ and 2.80 or the $\mathrm{OCH}_{2}$ protons at $\delta 4.10(\mathrm{t}$, minor) and 4.05 (t, major) were utilized. While for $\mathbf{3 b}$ in toluene- $\mathrm{d}_{6}, 1 \mathrm{H}$, dd at $\delta 5.05$ (major) and $4.98 \mathrm{ppm}$ (minor) were utilized, the signals at $\delta 4.13(\mathrm{t})$ (minor) and $4.08(\mathrm{t})$ (major) in $\mathrm{CD}_{3} \mathrm{OD}$ were used. For $3 \mathbf{c}$ in toluene- $\mathrm{d}_{6}$ and $\mathrm{CD}_{3} \mathrm{OD}$, Me triplets [at $\delta 0.80$ (minor) and 0.74 (major)] and $\mathrm{CO}_{2} \mathrm{Me}$ singlets [at $\delta 3.72$ (major) and 3.74 (minor)] were utilized, respectively. For 3d in toluene- $\mathrm{d}_{6}$ and $\mathrm{CD}_{3} \mathrm{OD}, \mathrm{C}(2) \mathrm{H}$ quintets [which was transformed to a doublets after irradiating $\mathrm{C}(2) \mathrm{Me}$ doublets] at $\delta 4.90$ (minor), 4.69 (major) in toluene- $\mathrm{d}_{6}$ and at $\delta 4.85$ (minor), 4.45 (major) in $\mathrm{CD}_{3} \mathrm{OD}$ were utilized.

Simulations of exchange affected triplets were carried out by modifying the two-site exchange program. ${ }^{16}$ The first order coupling to these protons is simply assumed as giving overlapping two site exchanges with the same population ratio and equal rates of exchange. 


\section{Acknowledgements}

The facilities provided by the King Fahd University of Petroleum and Minerals, Dhahran, are gratefully acknowledged.

\section{References}

1. (a) J. J. Tufariello I 1,3-Dipolar Cycloaddition Chemistry, Ed A. Padwa, Wiley-Interscience: New York 1984, 2, Ch 9, 83-168. (b) Confalone, P. N.; Huie, E. M. Org. React. 1988, 36, 1-173. (c) Dugovi, B.; Fisera, L.; Hametner, C.; Pronayova, N. ARKIVOC 2003, (xiv), 162.

2. (a) Tufariello, J. J. Acc. Chem. Res. 1979, 12, 396. (b) Ida, H.; Kibayashi, C. Yuki Gosei Kagaku Kyokaishi, 1983, 41, 652. (c) Revuelta, J.; Cicchi, S.; Goti, A.; Brandi, A. Synthesis 2007, No. 4, 485.

3. AlSbaiee, A.; Ali, S. A. Tetrahedron 2008, 64, 6635.

4. Riddel, F. G. Tetrahedron, 1981, 37, 849.

5. Raban, M.; Cost, D. Tetrahedron 1984, 40, 3345.

6. Raban, M.; Jones, Jr. F. B.; Carlson, E. H.; Bannuci, E.; LeBel, N. A. J. Org. Chem. 1970, 35, 1496, and references cited therein.

7. Wazeer M. I. M.; Ali, S. A. Magn. Reson. Chem. 1993, 31, 12.

8. (a) Ali, S. A.; Wazeer, M. I. M. Tetrahedron Lett. 1993, 34, 137. (b) Wazeer, M. I. M.; AlMuallem, H. A.; Ali, S. A. J. Phys. Org. Chem. 1993, 6, 326. (c) Kurteva, V. B.; Lyapova M. J.; Pojarlieff, I. G. ARKIVOC 2006, (ii), 91. (d) Ali, S. A.; Wazeer, M. I. M.; Fettouhi, M. B.; Iman, M. Z. N. ARKIVOC 2008, Accepted.

9. (a) Carruthers, W.; Coggins, P.; Weston, J. B. J. Chem. Soc. Perkin Trans. 1, 1990, 2323.

(b) Ali, S. A.; Wazeer, M. I. M. Tetrahedron Lett. 1992, 33, 3219.

10. Sanstrom, J. Dynamic NMR Spectroscopy, Academic Press: London, 1982.

11. Finke, H. L.; McCullough, J. P.; Messerly, J. F.; Osborn, A.; Douslin, D. R. J. Chem. Thermodyn. 1972, 4, 477-494.

12. Perzanowski, H. P.; Al-Jaroudi, S. S.;. Wazeer, M. I. M.; Ali, S. A. Tetrahedron 1997, 53, 11869.

13. Hootele, C.; Ibebeke-Bomangwa, W.; Driessens, F.; Sabil, S. Bull. Soc. Chim. Belg. 1987, $96,57$.

14. Kalinowski, H.; Berger S.; Braun, S. C-13 NMR Spectroscopy, Wiley, Chichester 1988.

15. The NMR Program Library, Science and Engineering Research Council, Daresbury Laboratory, Chesire, U. K.

16. Wazeer, M. I. M.; Ali, S. A. Canad. J. Appl. Spectry. 1993, 38, 22. 